Article

\title{
Sustainable Construction Safety Knowledge Sharing: A Partial Least Square-Structural Equation Modeling and A Feedforward Neural Network Approach
}

\author{
Rita Yi Man $\mathrm{Li}^{1}{ }^{1} * \mathbb{C}$, Beiqi Tang ${ }^{1}$ and Kwong Wing Chau ${ }^{2}(\mathbb{D}$ \\ 1 Department of Economics and Finance/HKSYU Real Estate and Economics Research Lab/Sustainable Real \\ Estate Research Centre, Hong Kong Shue Yan University, Hong Kong, China; h0339637@gmail.com \\ 2 Department of Real Estate and Construction, The University of Hong Kong, Hong Kong, China; \\ hrrbckw@hku.hk \\ * Correspondence: ymli@hksyu.edu; Tel.: +85225707110
}

Received: 6 September 2019; Accepted: 18 October 2019; Published: 21 October 2019

\begin{abstract}
Most studies focused on the introduction of new technologies have not investigated the psychological factors affecting the willingness to use them or conducted empirical studies to explore whether willingness and actual construction safety knowledge-sharing behavior are associated with fewer construction incidents. We conducted face-to-face and LinkedIn open-ended interviews as well as a global survey to study the willingness and actual behavior to share construction knowledge via social software Web 2.0, Internet of Things (IoT) and mobile apps. Then, the Partial Least Square-Structural Equation Model (PLS-SEM) for willingness and actual knowledge-sharing behavior, as well as the Multilayer Perceptron (MLP) Neural Network were used to illustrate the effect of various factors on predicting the willingness to share knowledge via Web 2.0, mobile apps and IoT. Results of the interviews found that practitioners use IoT for knowledge sharing, mainly because they do not want to fall behind the curve. PLS-SEM and MLP revealed that practitioners share construction safety knowledge are not driven by safety-related reasons such as safety awareness enhancement but perceived organization support from their companies. Employees who agree that their organization cared about their employees' well-being was the strongest predictor in influencing people's decision to use tools for knowledge sharing. Moreover, many respondents claimed that factors such as monetary rewards have little impact on motivating people to use tools for knowledge sharing.
\end{abstract}

Keywords: construction safety; Web 2.0; Internet of Things; mobile apps; artificial neural network; partial least square-structural equation model

\section{Introduction}

Construction safety and accident prevention is linked to the construction industry as well as the sustainability of the individual project $[1,2]$. As workers accumulate experience and skill at work, losing one worker due to an accident not only leads to financial losses, but also valuable industry knowledge. Adequate safety knowledge is a prerequisite to making the 'right' safety decisions, judgements, performance, and behavior [3]. Knowledge is often shared via different platforms [4], the most important being Web 2.0, IoT, and mobile apps. Web 2.0 enables users to write and change web content, share knowledge and socialize with others online [5] via online social networks such as Facebook, LinkedIn, YouTube, wikis, fora and folksonomies [6]. IoT enables information and knowledge exchange via a network of many connected 'things', such as radio-frequency identification (RFID), mobile phones and computers [7], and mobile apps are an integral part of people's daily lives. These platforms are also a meaningful way to share construction safety knowledge on construction 
sites, for example, Nourbakhsh, et al. [8] suggested that in Malaysia, workers used Microsoft Office SharePoint Server mobile app to report on-site accidents.

Many studies have examined the development of IoT and Web 2.0 tools. However, they have not investigated the psychological and informal institutional factors (anything outside the traditional black and white rules) that affect the willingness to share construction safety knowledge. Not to mention the psychological factors, such as Homans' propositions (HP), perceived organizational support (POS), leader membership exchange (LMX), and informal institutional factors. Furthermore, no research has been done to compare the motivators and barriers of construction safety knowledge sharing as compared to other types of knowledge sharing, nor building prediction model for people's willingness to use the tool. Therefore, this study aimed to fill this gap in research by using face-to-face and LinkedIn open-ended interviews, SmartPLS and MLP.

\section{Literature Review}

\subsection{Application of Web 2.0, Mobile Apps, and IoT Tools in the Construction Industry}

In the construction industry, mobile apps, IoT tools and Web 2.0 are applied for various uses, for example, mobile apps improve safety performance by providing a safety knowledge-sharing channel about potential chemical, fire and electrical hazards [9]. According to Liu [10], mobile apps offer the construction workers with affordable, quick, and user-friendly platforms to obtain necessary information. As such, there are nearly 13,000 construction apps in New Zealand alone. On the other hand, Web 2.0 helps construction worker to share knowledge. Thus, an internet forum with collaborative knowledge management solution in Finland's recorded 90\% workers' participation [6]. By contrast, IoT integrates devices and platforms by engaging the virtual and physical world [11]. Apart from using QR code (one application of IoT) for highway construction document management, IoT is used to detect safety threat and develop a proactive warning system that alert construction worker before getting close to hazards. Web-based portal systems with Radio Frequency Identification (RFID) improve the efficiency of on-site information-sharing [12]. Nonetheless, there is a lack of research regarding the motives of construction safety knowledge sharing via Web 2.0, IoT, and mobile apps.

\subsection{Motivations and Barriers of Knowledge Sharing by Social Software Web 2.0, IoT and Mobile Apps}

Previous research studied the motives and barriers of knowledge sharing via these tools in various industries except construction. Regarding IoT, improvement in participants' ability to reflect on what they learned motivated them to use it for knowledge sharing [13]. According to Zhang [14] development of the coordination mechanism and public service platforms motivates workers in the utility sector to share knowledge. On the other hand, people do not share knowledge via Web 2.0 mainly due to information security, confidentiality, openness, sensitivity and people not being ready to accept criticism from colleagues [15]. Concerning mobile apps, although people use them for teaching and learning purposes [16], they are reluctant to use them for knowledge sharing because different operating systems demands customized applications, or unwilling to be controlled when they use mobile apps [17]. Based on the previous literature, we hypothesised that the motivators and barriers in the construction industry to adopt the IoT, Web 2.0 and mobile apps for safety knowledge sharing are similar as the tools are the same (H1) (Table 1). 
Table 1. Factors that motivate or bar individuals from using various tools for construction safety knowledge sharing.

\begin{tabular}{|c|c|c|c|c|}
\hline Literatures & Country & Sector of Application & Factors that Motivate People to Share Knowledge & Barriers that Motivate People to Share Knowledge \\
\hline Chow, et al. [18] & Hong Kong & Milk outbound process & $\begin{array}{l}\text { IoT } \\
\text { Spot the possible procedure problems quickly and } \\
\text { deliver the correct knowledge to solve these problems }\end{array}$ & \\
\hline Sodhro, et al. [19] & & Health care & & $\begin{array}{l}\text { Battery energy management life and cycle of portage } \\
\text { or wearable devices. Connectivity of knowledge } \\
\text { sharing between stakeholders such as manufacturing } \\
\text { engineer and medical expert. }\end{array}$ \\
\hline Welbourne, et al. [20] & US & Intelligent buildings & Improvement in production processes & \\
\hline Zhang [14] & China & Utility & $\begin{array}{l}\text { Improvement in the production process, includes a } \\
\text { coordination mechanism and a public service platform }\end{array}$ & $\begin{array}{l}\text { High cost in integrating business resources, lack of } \\
\text { large-scale application, and inefficient business mode }\end{array}$ \\
\hline & & & Web 2.0 & \\
\hline $\begin{array}{l}\text { Bennett, Bishop, } \\
\text { Dalgarno, Waycott and } \\
\text { Kennedy [13] }\end{array}$ & Australia & Education & $\begin{array}{l}\text { Improve participants' ability to reflect what they } \\
\text { learned and helps develop thinking skills by writing } \\
\text { or producing related study materials }\end{array}$ & $\begin{array}{l}\text { Not enhancing participants' learning; sharing } \\
\text { knowledge did not assist their studies; atopic expertise } \\
\text { and academic qualifications were not improved }\end{array}$ \\
\hline Zhang, et al. [21] & Spain & Politics & $\begin{array}{l}\text { Political factors including ideology, political } \\
\text { competition or stability affect policymakers' } \\
\text { perceptions on the use of Web } 2.0 \text { technologies for } \\
\text { public sector knowledge sharing }\end{array}$ & \\
\hline Caruso [15] & & Not specific & $\begin{array}{l}\text { Web } 2.0 \text { tool is used more for knowledge sharing if } \\
\text { Employees cannot obtain relevant knowledge from } \\
\text { other communication channels. }\end{array}$ & $\begin{array}{l}\text { Information sensitivity, an unwillingness to share } \\
\text { unfinished work, the openness of information, a lack } \\
\text { of confidence to accept criticism on their contributions, } \\
\text { concern about security and confidentiality risks }\end{array}$ \\
\hline Ferguson [17] & & Education & $\begin{array}{c}\text { Interactive communication, potential extraction of } \\
\text { ideas from experts }\end{array}$ & $\begin{array}{l}\text { Time to adapt social community and confidence to } \\
\text { receive timely and appropriate responses }\end{array}$ \\
\hline Hsu and Park [22] & South Korea & Network infrastructure & $\begin{array}{l}\text { Strengthen interlinks between users with similar } \\
\text { preferences; ease to connect and manage people's } \\
\text { webspace to that of their friends }\end{array}$ & \\
\hline $\begin{array}{l}\text { Kulakli and Mahony } \\
\text { [23] }\end{array}$ & UK & Education & New functionalities, ease of use & $\begin{array}{l}\text { Institutional restrictions, academic's adoption, time } \\
\text { restraints, and privacy and confidentiality }\end{array}$ \\
\hline Mtega, et al. [24] & Tanzania & Education & $\begin{array}{l}\text { Training workshops promote the use and ease of Web } \\
2.0 \text {; improve agricultural productivity; reliable and } \\
\text { accessible communication channels and technologies }\end{array}$ & $\begin{array}{l}\text { Limited awareness and inadequate skills on Web } 2.0 \\
\text { tools }\end{array}$ \\
\hline Noh and Lee [25] & & Network infrastructure & Attitude and intention to use the blog & \\
\hline Said and Arcila [26] & $\begin{array}{l}\text { Latin } \\
\text { America }\end{array}$ & Network infrastructure & & $\begin{array}{l}\text { Misleading information, lack of users' interest in } \\
\text { communicative processes }\end{array}$ \\
\hline
\end{tabular}


Table 1. Cont.

\begin{tabular}{|c|c|c|c|c|}
\hline Literatures & Country & Sector of Application & Factors that Motivate People to Share Knowledge & Barriers that Motivate People to Share Knowledge \\
\hline & & & Mobile apps & \multirow{4}{*}{$\begin{array}{l}\text { Difficulty in search and retrieve appropriate mobile } \\
\text { application }\end{array}$} \\
\hline Einav, et al. [27] & US & Emerging business model & Mobile application interface and platform design & \\
\hline Furlong, et al. [28] & Australia & Healthcare & & \\
\hline Handal, et al. [29] & Australia & Education & Improvement in teaching processes & \\
\hline Hoang and Caverly & US & Education & $\begin{array}{l}\text { Improvement in teaching (instruction, advice, and } \\
\text { feedback) process }\end{array}$ & \multirow{3}{*}{$\begin{array}{l}\text { User are reluctant to be "controlled" to use mobile } \\
\text { application }\end{array}$} \\
\hline Kenny, et al. [30] & Ireland & Healthcare & $\begin{array}{c}\text { Anonymous data collection for health status } \\
\text { assessment }\end{array}$ & \\
\hline Sim, et al. [31] & & Healthcare & $\begin{array}{l}\text { Convenience to communicate, particularly between } \\
\text { doctor and patients }\end{array}$ & \\
\hline Thornton, et al. [32] & Australia & Healthcare & & \multirow[t]{2}{*}{ Poor quality mobile application } \\
\hline Wai, et al. [33] & Hong Kong & Education & $\begin{array}{l}\text { The apps are useful in improving students' academic } \\
\text { performance }\end{array}$ & \\
\hline
\end{tabular}


2.3. Knowledge Sharing and Psychology: Homan Proposition (HP), Perceived Organisation Support (POS), and Leader Membership Exchange (LMX)

Powell and Dalton [34] proposed that HP comprises of the value proposition, that is, people repeat an act if the reward of that act is valuable. And success proposition which suggests that people tend to repeat the same act if they are rewarded for the activity. Wang et al. [35] suggested that the characteristics and expected rewards of the knowledge affected the possibility of knowledge sharing in high-technology companies. Research into any of HP psychological factor is rare, but the literature identified provides grounds for hypothesis $\mathrm{H} 4$.

POS echoes the perceived organization concerns regarding employees' well-being and values their contributions to the companies, leading to employees' different expectation on their effort which will be rewarded. Employees possess higher POS exhibit stronger commitments at work [36]. Likewise, POS had a positive and significant impact on the Norwegian oil and gas industry' knowledge sharing activities [37]. Li [38] noted that employees with better POS recorded lower incidents through the mediating effect of safety communication and commitment in the manufacturing sector, and proposed a conceptual framework in which POS affected employees' perceptions of the organizational safety climate. Thus, we hypothesize that employees with better perceived POS are more likely to share construction safety knowledge at work (H2).

LMX concerns the vertical relationships between subordinates and managers. Better LMX results in more resources being available to subordinates and restricted information [39]. Employees in a mobile phone company with better LMX, characterized with a high degree of mutual trust, were more willing to share their knowledge [40]. When we apply the same analogy, employees with better perceived LMX share more construction safety knowledge (H3).

\subsection{Informal Institution Settings and Knowledge Sharing}

Institutions are rules of games in a society which affect our behaviors [41]. People can be forced by formal institutions, such as laws and regulations to share knowledge. Additionally, informal institutions like cultures can provide insights to construction worker that may make them willing to share knowledge. However, cultures differ among locals and migrants, different generations, nations as well as ethnic minorities.

According to Sanaei, et al. [42] construction workers comes from three generations. Generation Y (1981-1999) get used to social media information technology. Generation X (1965-1980) favour informational learning. Thus, they only pick formal training if there is no other option. 'Digital immigrant baby boomers' generation are comfortable with knowledge sharing over phone or through face-to-face communication. Their research found that there were significant differences in knowledge sharing via instant messaging, echoed with other studies which suggested different ages shared different viewpoints [43].

When we conceptualize the role of institutions in economic geography, a natural starting point is to consider the incentives that affect people's action. Arpaci and Baloglu [44] found that culture exhibited a significant positive impact on attitudes and norms of knowledge sharing among undergraduates. The effect of a willingness to share construction safety knowledge due to the cultural differences has rarely been examined. Nevertheless, the literature provides grounds for our speculation that locals and migrants or even generations who have different cultural backgrounds/norms, may have different levels of willingness to share knowledge via Web 2.0, IoT and mobile apps (H5).

\subsection{Willingness and Actual Behavior}

Although knowledge-sharing properties and tools affect an individual's desire to share knowledge, there is a lack of research into the willingness to share construction safety knowledge via IoT, Web 2.0 and mobile apps. The previous study primarily examined the willingness to pay, for example, Rodiger et al. [45] investigated the desire to spend and real purchase for organic food. It was found that people do not usually act due to practicality reasons. For example, they feel that they have 
no responsibility, are not obligated to do, cannot change the situation at hand, or lack of time [46]. Wang et al. [35] suggested that knowledge-sharing behavior was linked to willingness.

Shin, et al. [47] projected an RFID-based framework that combined legacy systems to facilitate communication. Nevertheless, knowledge sharing does not depend solely on ontologies. The willingness to use technologies for sharing construction safety knowledge is also essential. Many research developed new safety knowledge-sharing technologies but not the desire to use them.

We conjecture that willingness leads to the actual knowledge-sharing behavior via these technologies which reduces incidents eventually (H6). Nevertheless, the practicality issues lower people's incentives in sharing knowledge through these tools (H7). Based on the results regarding the six hypotheses, we then studied the possibility of utilizing the most impactful factor to predict people's likelihood of using these tools for knowledge sharing.

\section{Research Method}

This study involved three stages 1) interviews/open-ended LinkedIn interview, followed by text mining of the results. 2) we utilized a close-ended questionnaire, and PLS-SEM was used to identify the crucial factors that affect the willingness and actual knowledge-sharing behaviors. 3) We predict knowledge-sharing activities via a feedforward neural network. Information inconsistencies were clarified by triangulating data and methods from multiple sources to enhance credibility [48].

\subsection{Interviews and Text mining}

Facebook and WhatsApp are commonly used applications, but the layperson may not be familiar with IT terminology such as IoT. A five-minute video on the definition and application of Web 2.0, IoT and mobile apps was shown to interviewees to avoid any misunderstanding of technical terms. A similar technique was used in information science research [49], which helped interviewees learn more about the issues and prompt discussion in interviews. Open-ended questions increased flexibility and the depth of information collected.

Invitations were sent to individuals listed as construction practitioners in LinkedIn, all companies listed in the Hong Kong Special Administrative Region Government List of Approved Contractors in Development Bureau requesting interviews. The snowball method increased the number of interview participants, and the results were analyzed using text analytics and content analysis [48]. Respondents' viewpoints were compared by studying the co-occurrence of concepts mentioned by the interviewees [50]. The results, including the factors that motivate and bar people from adopting Web 2.0, IoT and mobile apps for knowledge sharing, were tokenized to parse the body of text into terms.

\subsection{Surveys, PLS-SEM and MLP Prediction}

The results of the literature review and interviews provided the basis of the questionnaire design. Definitions of IoT, Web 2.0 and mobile apps were presented in the questionnaires to enhance measurement validity and reliability (Abowitz \& Toole 2010). Questionnaires with 5-point Likert scale questions were used to assess construction practitioners' perceptions [51] (see full list questions in Table 4). PLS-SEM was used to study the causal relationship between leader membership exchange, POS, Homan's proposition, and institutional factors such as education, willingness to share various tools, actual knowledge-sharing behavior and construction accidents. The PLS-SEM algorithm was used to calculate the path coefficient of the structural model between -1 and +1 , where the positive and highly correlated value is closer to +1 , the negative and highly correlated value is closer to -1 , the closer the value to 0 , the weaker the relationship [52].

Chong and Bai [53] suggested that a good quality neural network for prediction could be obtained by selecting the most significant hypothesized variables through structural equation modelling to determine the required inputs before making predictive models via the neural network. Thus, the most influential factor indicated in PLS-SEM which affect the willingness to share knowledge into the feed-forward artificial neural network (ANN) MLP was included to investigate which factors better predict the likelihood of knowledge sharing. 
Neural networks have rarely been applied in construction research, except in a study of concrete dispatch conducted by Maghrebi, et al. [54]; however, they did not use feedforward MLP. MLP ANN works on the principle of the human nervous system, learning and making data predictions. The neural structure is inter-connected by many processing elements, known as neurons, which receive information from other sources, perform non-linear operations on the output results, then produce the final output. It first learns, then stores the data with weights, with algorithms to adjust the weights and reduce biases in the training process, the error between actual and predicted values. The main advantage lies on its ability to solve complex problems fast. The basic structure of multilayer perception consists of three layers: the first input layer, middle hidden layer and last output layer, with the product of input elements (ai) and weights (wij) fed to summing junctions with bias (bj) of neurons as follows [55]:

$$
X=\left(\sum_{\mathrm{i}=1}^{\mathrm{n}} \mathrm{w}_{\mathrm{ij}} \mathrm{a}_{\mathrm{i}}\right)+\mathrm{b}_{\mathrm{j}}
$$

Then, the sum passes through the transfer function $\mathrm{F}$, which generates the output:

$$
\mathrm{F}(\mathrm{X})=\mathrm{u}_{\mathrm{j}}=\mathrm{F}\left[\left(\sum_{\mathrm{i}=1}^{\mathrm{n}} \mathrm{w}_{\mathrm{ij}} \mathrm{a}_{\mathrm{i}}\right)+\mathrm{b}_{\mathrm{j}}\right]
$$

Hidden layer activation function, including hyperbolic tangent or exponential was used.

\section{Results}

\subsection{Interview / LinkedIn Open-End Interview Results}

Among the 134 global respondents, participants suggested that they wished to know more about construction safety, upgrade their knowledge via Web 2.0 and enhance their safety awareness. Many construction practitioners were not aware of Web 2.0 and did not want to use a phone during work, while some considered that the older generation does not know Web 2.0. Moreover, the information on the internet may be incorrect. An assistant engineer who mainly works for a tunnel project in China suggested that people are motivated to use Web 2.0: "more people understand the safety knowledge in the construction process, discover the safety hidden danger in time, and solve it timely can largely reduce construction accidents". It also depended on the complexities of projects, project parties and other factors. Regarding factors that demotivate construction practitioners from using Web 2.0 for knowledge sharing, another engineer who worked for sewers suggested that "no one is encouraged to play on his own phone during work, especially in construction sites, whereas a phone is the most accessible electronic machine."

Many people suggested that safety knowledge increases by using mobile apps. A site worker from Hong Kong commented: "I think the people who do this are the ones that want others to have the understanding of safety knowledge directly." However, many people, especially the older generations, do not know how to use mobile apps and are worried that workers are hit by vehicles when they use apps. An engineer who worked for road, sewage, and drains commented that the use of mobile apps is not recommended, being regarded as "another safety issue, phones are usually prohibited during construction works. Imagine a place with possible falling objects, people work at height, tower cranes lifting materials, and cars moving in the corridors. Are you sure you are going to check out the phone and read a safety notification?"

Regarding IoT, many people consider that the use of IoT is an excellent way to keep pace with technology. A construction superintendent suggested, "since safety problems are the most important thing, knowing more about this knowledge can better protect ourselves." People do not use IoT to share knowledge as sharing safety knowledge via IoT is boring or as an engineering assistant suggested, "people may not have related knowledge about the Internet of Things". Tables 2 and 3 show the highest frequency factors that motivated and prevented individuals from sharing construction safety knowledge mentioned by the construction practitioners. The interview results confirmed the hypothesis that practicality issues reduce people's incentives in sharing knowledge (H7). 
Table 2. Text mining results regarding factors that motivate individuals to share construction safety knowledge.

\begin{tabular}{|c|c|c|c|c|c|}
\hline Web 2.0 & Count & Mobile Apps & Count & Iot & Count \\
\hline people awareness & 3 & safety knowledge & 4 & industries better follow the pace & 3 \\
\hline safety awareness & 3 & via mobile & 4 & the pace of the technology era & 3 \\
\hline good to upgrade & 3 & knowledge via mobile apps & 3 & practices in construction industries better & 3 \\
\hline industry to match & 3 & knowledge via mobile & 3 & better follow the pace & 3 \\
\hline people can know & 3 & make more people & 3 & construction industries better follow & 3 \\
\hline practices in construction & 3 & knowledge via & 3 & the pace of the technology & 3 \\
\hline upgrade the practices & 3 & many people & 3 & practices in construction industries & 3 \\
\hline construction industry to match & 3 & smart phone & 3 & construction industries better & 3 \\
\hline guess it is good & 3 & & & follow the pace & 3 \\
\hline match with the technology & 3 & & & industries better follow & 3 \\
\hline \multirow[t]{6}{*}{ practices in construction industry } & 3 & & & practices in construction & 3 \\
\hline & & & & sharing safety knowledge & 3 \\
\hline & & & & better follow & 3 \\
\hline & & & & construction industries & 3 \\
\hline & & & & sharing safety & 3 \\
\hline & & & & technology era & 3 \\
\hline
\end{tabular}


Table 3. Text mining results regarding factors that prevent the individuals to share construction safety knowledge.

\begin{tabular}{|c|c|c|c|c|c|}
\hline Web 2.0 & Count & Mobile Apps & Count & IoT & Count \\
\hline know how to use & 8 & safety knowledge & 10 & know how to use & 4 \\
\hline share safety knowledge & 6 & know how to use & 9 & much information & 4 \\
\hline safety knowledge via & 5 & may not know & 5 & people may & 4 \\
\hline share safety knowledge via & 4 & use the apps & 5 & safety knowledge & 4 \\
\hline especially in construction sites whereas & 3 & another safety issue phones & 3 & use internet & 3 \\
\hline one is encouraged to play & 3 & cars moving in the corridors & 3 & & \\
\hline phone is the most accessible & 3 & another safety issue phones & 3 & & \\
\hline play on his own phone & 3 & cars moving in the corridors & 3 & & \\
\hline work especially in construction sites & 3 & check out the phone & 3 & & \\
\hline construction sites whereas phone & 3 & construction works imagine a place & 3 & & \\
\hline especially in construction sites & 3 & cranes lifting materials and cars & 3 & & \\
\hline phone during work especially & 3 & falling objects people work & 3 & & \\
\hline safety knowledge via web & 3 & generation may not know & 3 & & \\
\hline work especially in construction & 3 & gonna check out the phone & 3 & & \\
\hline accessible electronic machine & 3 & height tower cranes lifting materials & 3 & & \\
\hline construction sites whereas & 3 & imagine a place with possible & 3 & & \\
\hline encouraged to play & 3 & issue phones are usually prohibited & 3 & & \\
\hline especially in construction & 3 & lifting materials and cars moving & 3 & & \\
\hline face-to-face & 3 & materials and cars moving & 3 & & \\
\hline may not know & 3 & moving in the corridors & 3 & & \\
\hline may not use & 3 & objects people work at height & 3 & & \\
\hline phone during work & 3 & older generation may not know & 3 & & \\
\hline sites whereas phone & 3 & people work at height tower & 3 & & \\
\hline accessible electronic & 3 & phone and read a safety & 3 & & \\
\hline much information & 3 & phones are usually prohibited & 3 & & \\
\hline old age & 3 & place with possible falling objects & 3 & & \\
\hline older generation & 3 & possible falling objects people work & 3 & & \\
\hline sites whereas & 3 & prohibited during construction works & 3 & & \\
\hline \multirow{6}{*}{ work especially } & 3 & read a safety notification & 3 & & \\
\hline & & safety issue phones are usually & 3 & & \\
\hline & & safety notification & 3 & & \\
\hline & & tower cranes lifting materials & 3 & & \\
\hline & & usually prohibited during construction works & 3 & & \\
\hline & & work at height tower cranes & 3 & & \\
\hline
\end{tabular}




\subsection{Questionnaire Results}

Questionnaires were sent to all registered LinkedIn account users who labelled themselves as working in the construction industry, with a total of 602 completing the surveys. Respondents usually work in China, the US, Europe and Australia etc. over the past five years (Figure 1). Most respondents were male (408), reflecting the male-dominated construction industry. Among all the leader membership exchange questions, the most significant number of respondents agreed with the statement "I respect my supervisor's knowledge and competency on the job". The least number of respondents agreeing to the statement "If I make a mistake, my boss protects me against others." Surprisingly, only 295 out of 602 respondents agreed that they were more willing to share construction safety knowledge if there was a valuable reward, which was the lowest number of respondents to coincide with a statement. Table 4 shows that results of the questionnaires such as the psychological factors (LMX, POS, and HP), institutional factors and some other factors impacted the willingness to share construction safety knowledge via Web 2.0.

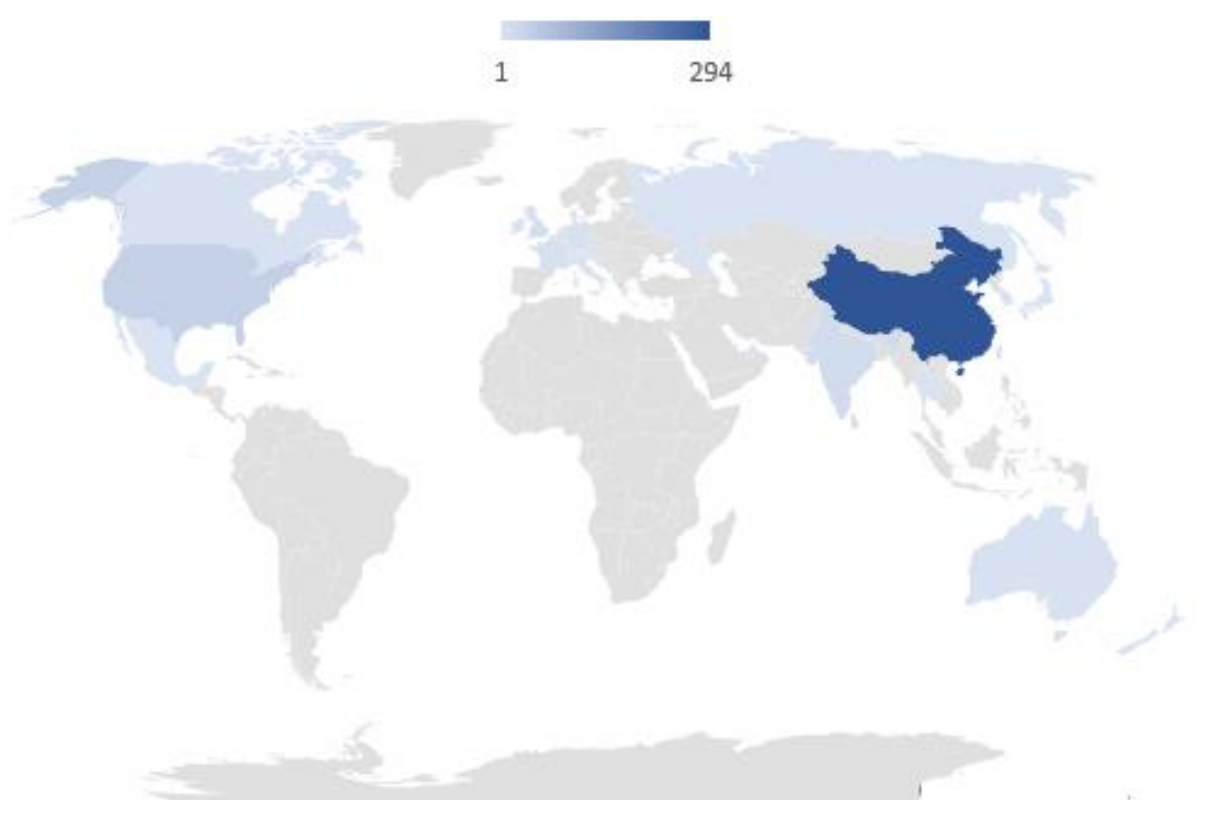

Figure 1. Places of work of the respondents over the past five years.

Table 4. List of the survey questions.

\begin{tabular}{cccc}
\hline & Questions & Yes & No \\
\hline L1 & I like my supervisor as a person & $77.1 \%$ & $22.9 \%$ \\
L2 & Everybody tends to like my supervisor as a friend & $63.0 \%$ & $37.0 \%$ \\
L3 & I feel pleasure when I work with my superior & $69.6 \%$ & $30.4 \%$ \\
L4 & My boss supports me as a superior even if he doesn't have enough & $66.9 \%$ & $33.1 \%$ \\
L5 & information about my activities & $65.0 \%$ & $35.0 \%$ \\
L6 & When I was attacked by others, my boss defended me & $58.0 \%$ & $42.0 \%$ \\
L7 & If I make a mistake, my boss protects me against others & $59.6 \%$ & $40.4 \%$ \\
L8 & I do more than my regular work just to please my superior & $71.8 \%$ & $28.2 \%$ \\
L9 & I am ready to work my hardest for my boss & $71.4 \%$ & $28.6 \%$ \\
L10 & I admire my boss's professional knowledge & $75.6 \%$ & $24.4 \%$ \\
L11 & I respect my supervisor's knowledge and competency on the job & $80.1 \%$ & $19.9 \%$ \\
L12 & I admire my supervisor's professionalism and competency on the job & $79.9 \%$ & $20.1 \%$ \\
H1 & Would you be more willing to share construction safety knowledge if & $49.0 \%$ & $51.0 \%$ \\
I5 & there was a valuable reward? & $10.5 \%$ & $89.5 \%$ \\
I6 & Are you a migrant? & $5.3 \%$ & $94.7 \%$ \\
I7 & Are you from an ethnic minority? & $74.4 \%$ & 25.6 \\
\hline
\end{tabular}


Table 4. Cont.

\begin{tabular}{|c|c|c|c|c|}
\hline & Questions & Yes & No & \\
\hline & & Male & Female & \\
\hline \multirow{2}{*}{$\mathrm{I} 4$} & Sex & $67.9 \%$ & $32.1 \%$ & \\
\hline & & $0-50$ & 51-100 & 101-150 \\
\hline \multirow[t]{4}{*}{ I8 } & $\begin{array}{c}\text { Company size (number of people: } 0-50,50-100,100-150,150-200,200 \text { or } \\
\text { above) }\end{array}$ & $28.1 \%$ & $14.4 \%$ & $9.8 \%$ \\
\hline & & 151-200 & $>200$ & \\
\hline & & $8.3 \%$ & $39.4 \%$ & \\
\hline & & Mean & Median & SD \\
\hline I1 & Age & 33 & 30 & 10 \\
\hline $\mathrm{I} 2$ & $\begin{array}{c}\text { Education (Secondary school or below }=1 ; \text { Associate degree/diploma }=2 \text {, } \\
\text { undergraduate }=3, \text { Postgraduate }=4 \text { ) }\end{array}$ & 2.71 & 3 & 0.98 \\
\hline I3 & Work experience in construction industry (years) & 9.21 & 6 & 9.69 \\
\hline I9 & How many years have you worked for this company? & 5.45 & 3 & 7.21 \\
\hline
\end{tabular}

Figure 2 shows that the relationship between willingness to share construction knowledge via Web 2.0 with construction accidents was 0.151 . Still, the actual behavior of construction safety knowledge sharing via Web 2.0 recorded a negative relationship with accidents -0.027 . Also, the willingness to share construction knowledge via Web 2.0 affected (0.275) the actual behavior using Web 2.0 to share construction safety knowledge. Perceived organization support had the most substantial impact (0.349), with institutional factors having little effect on the willingness to share construction safety knowledge via Web 2.0. Support of the boss (L4) imposed a substantial influence on leader membership exchange (0.532). Education level (I2) had the most definite impact on the institutional factors, with higher educated practitioners being more willing to share construction safety knowledge. The number in the three latent variables is $\mathrm{R}$ square, that shows how well the regression predictions approximate the real data points, the data is between 0 to 1 and $R$ square of 1 indicates that the regression predictions perfectly fit the data.

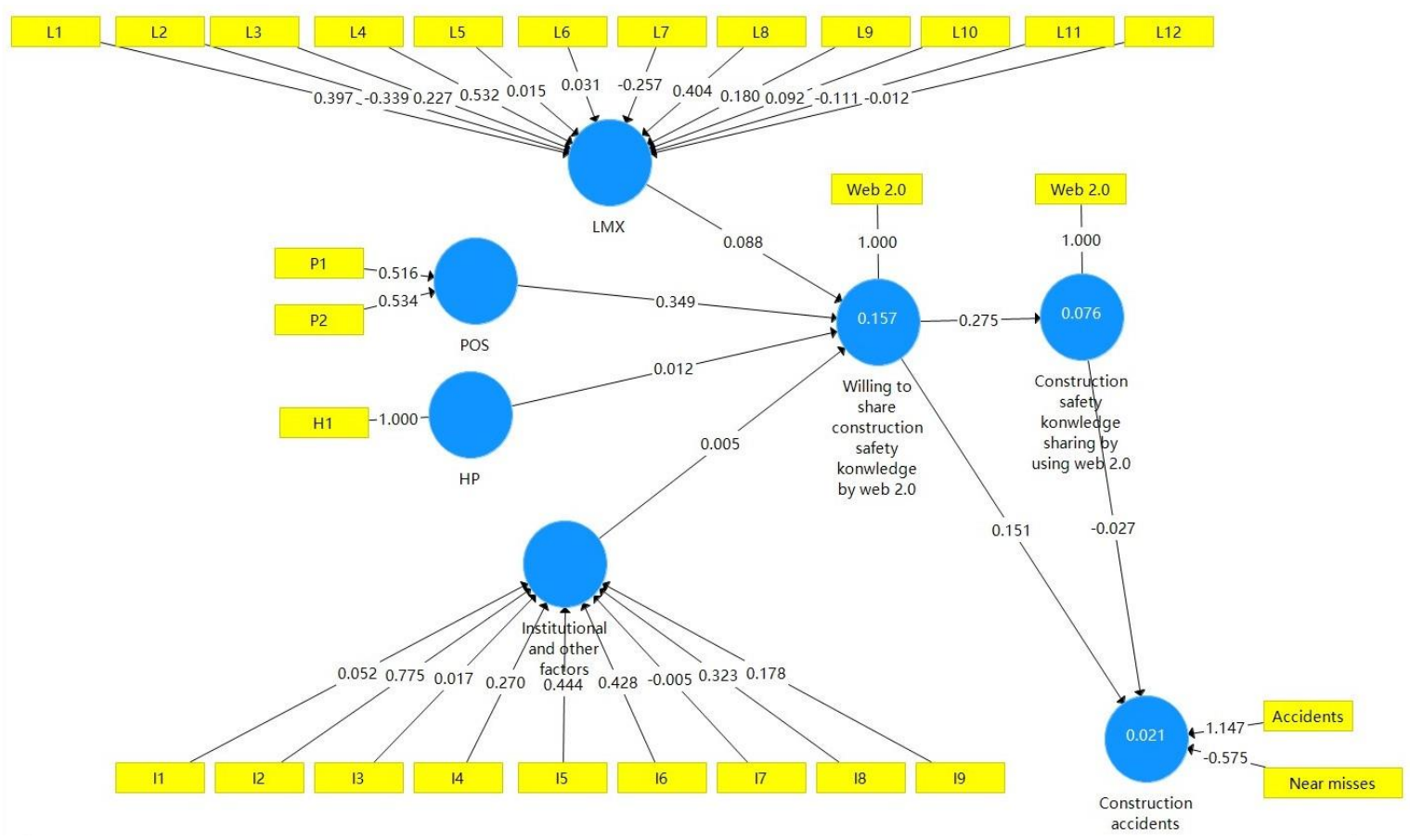

Figure 2. SmartPLS results of Web 2.0.

Figure 3 shows that the willingness to share construction knowledge via mobile apps positively affected the actual behavior of sharing construction safety knowledge by mobile phones (0.249). Perceived organization support (POS) has the most impact (0.306), with Homan proposition (HP) 
having little effect on the willingness to share construction safety knowledge via mobile apps $(0.003)$. The support of the boss (L4) predicted well for the leader membership exchange (LMX), while the efforts put to fulfil the boss's objective (L8) had little effect on the LMX. The migrate situation (I6) had the most impact on the institutional factors and other factors, while gender (I4) had little effect. The R square of the three variables (i.e. "willing to share construction safety knowledge by mobile apps", "construction safety knowledge sharing by using mobile apps", and "construction accident") fell between 0 and 1 , indicating an acceptable level.

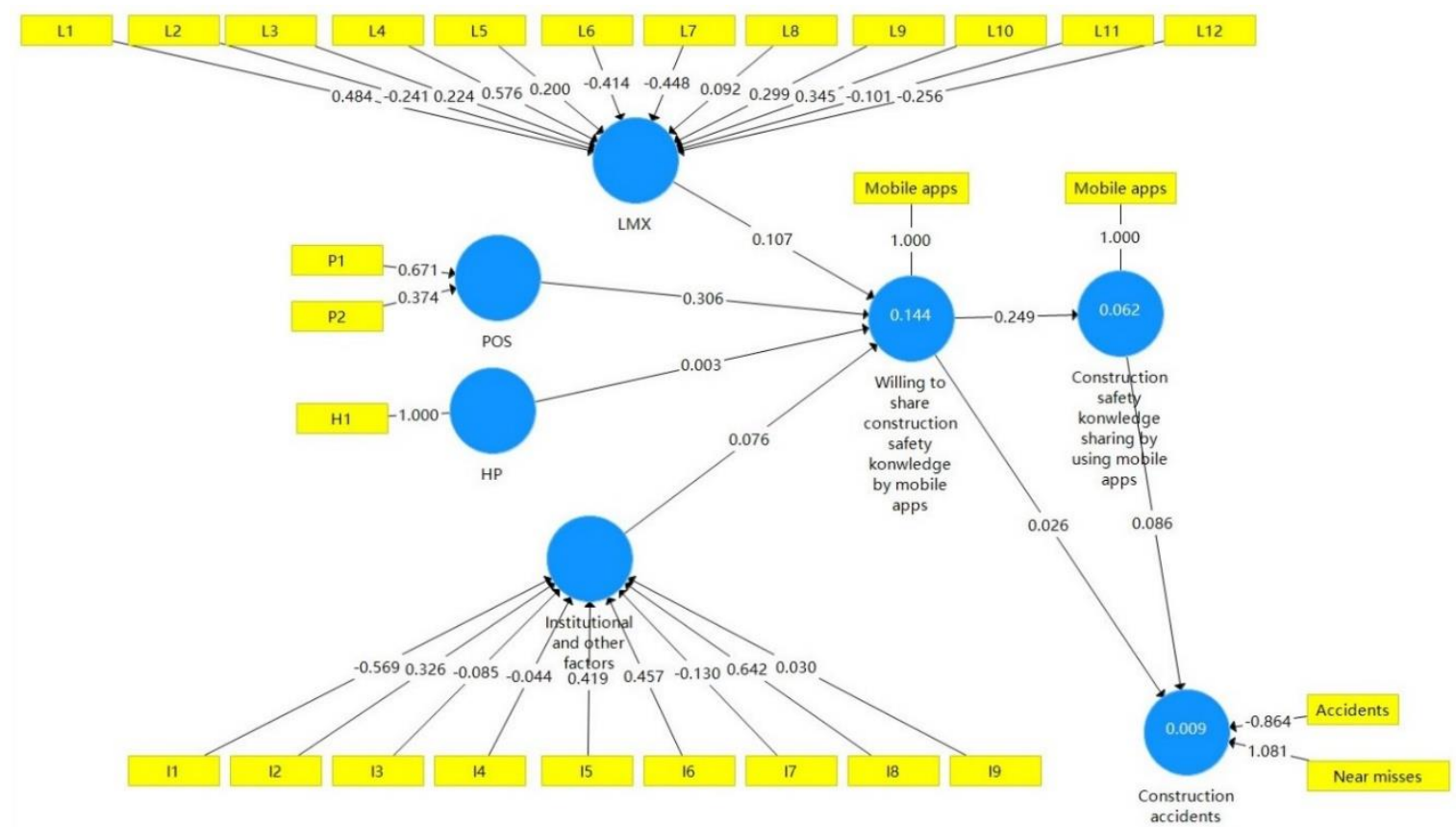

Figure 3. SmartPLS results for mobile apps.

Figure 4 shows that practitioners who are more willing to share construction safety knowledge by IoT had a lower construction accident rate. The actual usage of IoT construction safety knowledge sharing using IoT for knowledge sharing, however, records a positive relationship of 0.101 . Besides, the willingness to share construction knowledge by IoT positively (0.376) affected the actual behavior of using IoT to share construction safety knowledge. The R square of the three independent variables (i.e. "willing to share construction safety knowledge by IoT", "construction safety knowledge sharing by using IoT", and "construction accident") was between $0-1$, so was an acceptable level.

POS had the most potent prediction power (0.392), and HP had little affect (0.036) on the willingness to share construction safety knowledge via IoT. The efforts to fulfil the boss's objective (L8) predicted well for the LMX, while the preference of the supervisor (L1) had little effect on the LMX. The age of people (I1) had the most negative impact on the institutional factors and other factors, while the duration of work experience (I3) had little effect. 


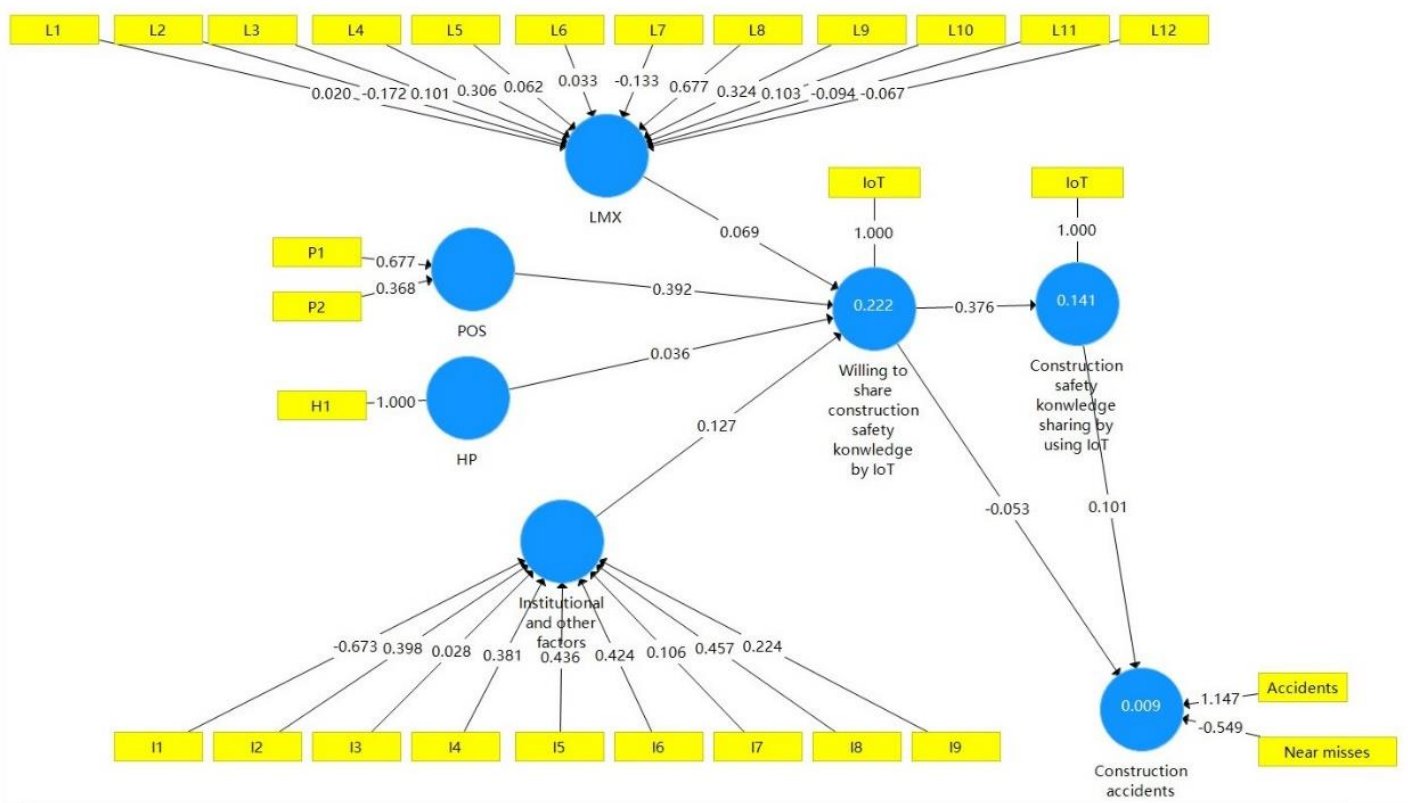

Figure 4. SmartPLS results for IoT.

\subsection{Feedforward Neural Network Results}

The predictive algorithms for willingness and actual knowledge-sharing behaviour based on the MLP neural network illustrated the effect of various factors on predicting the desire to share the knowledge via Web 2.0, mobile apps and IoT (Tables 5 and 6). It was found that employees who agreed that their organisation cared about employees' well-being was the strongest predictor influencing people's decisions regarding the use of tools for knowledge sharing, which was particularly true for IoT. Willingness to share knowledge using these tools was an essential factor promoting actual usage. 
Table 5. MLP results regarding various factors' predictive power on using Web 2.0, IoT and mobile apps.

\begin{tabular}{|c|c|c|c|c|c|c|c|c|c|c|c|c|c|}
\hline \multicolumn{14}{|c|}{$\begin{array}{ll}\text { Parameter Estimates } \\
\end{array}$} \\
\hline \multirow{2}{*}{\multicolumn{2}{|c|}{ Predictor }} & \multicolumn{4}{|c|}{ Predicted $($ Web 2.0) } & \multicolumn{4}{|c|}{ Predicted (Mobile Apps) } & \multicolumn{4}{|c|}{ Predicted (IoT) } \\
\hline & & \multicolumn{3}{|c|}{ Hidden Layer } & \multirow{2}{*}{$\begin{array}{c}\begin{array}{c}\text { Output } \\
\text { Layer }\end{array} \\
\text { H (1:2) }\end{array}$} & \multicolumn{3}{|c|}{ Hidden Layer } & \multirow{2}{*}{$\begin{array}{l}\text { Output } \\
\text { Layer }\end{array}$} & \multicolumn{3}{|c|}{ Hidden Layer } & \multirow{2}{*}{$\begin{array}{r}\begin{array}{r}\text { Outpu } \\
\text { Layer }\end{array} \\
\text { H (1:3) }\end{array}$} \\
\hline & & H (1:1) & H (1:2) & H (1:1) & & H (1:1) & H (1:2) & H (1:3) & & & H (1:1) & H (1:2) & \\
\hline \multirow{7}{*}{$\begin{array}{l}\text { Input } \\
\text { Layer }\end{array}$} & (Bias) & -0.433 & 0.142 & 0.387 & & -0.149 & -0.212 & 0.019 & & -0.607 & 0.491 & 0.052 & \\
\hline & P1 & 0.165 & -0.217 & 0.793 & & -0.077 & -0.935 & -0.582 & & 0.686 & 0.202 & -0.188 & \\
\hline & L4 & -0.095 & 0.144 & 0.407 & & -0.441 & -0.163 & -0.100 & & -0.056 & -0.268 & 0.344 & \\
\hline & L8 & 0.387 & -0.142 & -0.255 & & -0.063 & 0.122 & 0.001 & & -0.068 & 0.530 & -0.137 & \\
\hline & H1 & 0.464 & -0.100 & -0.319 & & -0.112 & -0.052 & 0.102 & & 0.193 & -0.442 & -0.014 & \\
\hline & $\mathrm{I} 2$ & 0.188 & -0.092 & 0.121 & & -0.359 & 0.117 & -0.010 & & -0.446 & 0.397 & 0.454 & \\
\hline & I5 & -0.157 & -0.319 & 0.100 & & -0.478 & 0.147 & -0.408 & & 0.105 & -0.787 & 0.627 & \\
\hline \multirow{4}{*}{$\begin{array}{l}\text { Hidden } \\
\text { Layer } 1\end{array}$} & (Bias) & & & & -0.055 & & & & -0.072 & & & & 0.213 \\
\hline & $\mathrm{H}(1: 1)$ & & & & 0.206 & & & & 0.056 & & & & 1.130 \\
\hline & $\mathrm{H}(1: 2)$ & & & & -0.160 & & & & -0.390 & & & & 0.617 \\
\hline & $\mathrm{H}(1: 3)$ & & & & 0.390 & & & & -0.135 & & & & 0.548 \\
\hline
\end{tabular}

Table 6. Factors' predictive power on using Web 2.0, IoT and mobile apps.

\begin{tabular}{|c|c|c|c|}
\hline Questions Include in the Predictive Model and the Corresponding Hypotheses & Web 2.0 & Mobile Apps & IoT \\
\hline Organization cared about employees' well-being (H2) & 0.37 & 0.439 & 0.797 \\
\hline Boss supports the employee as a superior, even if he doesn't have enough information about staff activities (H3) & 0.116 & 0.052 & -0.040 \\
\hline I put in more effort than the job requires to fulfil my manager's objectives (H3) & 0.003 & -0.051 & 0.175 \\
\hline Valuable reward for knowledge sharing $(\mathrm{H} 4)$ & -0.013 & 0.0002 & -0.062 \\
\hline Education (H5) & 0.101 & -0.064 & -0.010 \\
\hline Migrant (H5) & 0.058 & -0.029 & -0.023 \\
\hline Willingness to share construction safety knowledge lead to actual knowledge-sharing behavior (H6) & 0.275 & 0.249 & 0.376 \\
\hline Actual knowledge-sharing behavior's impact on construction accidents (H6) & -0.027 & 0.086 & 0.101 \\
\hline
\end{tabular}


All in all, our results indicated that POS was the most important driver in construction safety knowledge sharing by these tools. Interestingly, while we may perceive monetary reward motivate people to share safety knowledge, that was not a major driver. Table 7 summarizes our research findings.

Table 7. Summary of research findings.

\begin{tabular}{|c|c|c|c|}
\hline Hypotheses & $\begin{array}{c}\text { Text Mining Results of } \\
\text { Interviews/Open-Ended } \\
\text { Survey }\end{array}$ & PLS-SEM Results & $\begin{array}{l}\text { Feed forward Neural } \\
\text { Network Results }\end{array}$ \\
\hline $\begin{array}{l}\text { H1: the motivators and } \\
\text { barriers in the construction } \\
\text { industry to adopt the IoT, } \\
\text { Web } 2.0 \text { and mobile apps for } \\
\text { safety knowledge sharing } \\
\text { are similar as the tools are } \\
\text { the same. }\end{array}$ & $\begin{array}{l}\text { Practitioners use IoT to } \\
\text { follow the pace of } \\
\text { technology, but more are } \\
\text { motivated to use Web } 2.0 \\
\text { and mobile apps to } \\
\text { enhance safety } \\
\text { awareness and } \\
\text { knowledge respectively }\end{array}$ & $\begin{array}{c}\text { POS is the strongest } \\
\text { motivator to share safety } \\
\text { knowledge among all the } \\
\text { tools investigated }\end{array}$ & $\begin{array}{l}\text { POS is the strongest } \\
\text { motivator to share the safety } \\
\text { knowledge among all the } \\
\text { tools investigated }\end{array}$ \\
\hline $\begin{array}{l}\text { H2: employees with better } \\
\text { POS are more likely to share } \\
\text { construction safety } \\
\text { knowledge at work }\end{array}$ & $X$ & $\checkmark$ & $\checkmark$ \\
\hline $\begin{array}{l}\text { H3: employees with better } \\
\text { perceived LMX are more } \\
\text { likely to share construction } \\
\text { safety knowledge }\end{array}$ & $X$ & Weak & $\begin{array}{l}\text { Weak or negative } \\
\text { relationship }\end{array}$ \\
\hline $\begin{array}{l}\text { H4: properties of shared } \\
\text { knowledge, expected } \\
\text { rewards and incentives } \\
\text { affected the likelihood of } \\
\text { knowledge sharing }\end{array}$ & $x$ & Weak & $\begin{array}{l}\text { Very weak or negative } \\
\text { relationship }\end{array}$ \\
\hline $\begin{array}{l}\text { H5: locals and migrants or } \\
\text { generations with different }\end{array}$ & & $\begin{array}{l}\text { Migrants have the strongest } \\
\text { willingness to share }\end{array}$ & \\
\hline $\begin{array}{l}\text { cultural backgrounds/norms } \\
\text { may have different levels of } \\
\text { willingness to share } \\
\text { knowledge via Web 2.0, IoT } \\
\text { and mobile app }\end{array}$ & NA & $\begin{array}{l}\text { knowledge via Web 2.0; } \\
\text { practitioners from larger } \\
\text { firms are more willing to } \\
\text { share safety knowledge via } \\
\text { mobile apps and IoT }\end{array}$ & $\begin{array}{l}\text { Education and migrants } \\
\text { display a weak or negative } \\
\text { relationship }\end{array}$ \\
\hline $\begin{array}{l}\text { H6: willingness leads to } \\
\text { actual knowledge-sharing } \\
\text { behavior through these } \\
\text { technologies, thus reduces } \\
\text { incidents }\end{array}$ & NA & $\begin{array}{l}\text { Weak relationship between } \\
\text { willingness and actual } \\
\text { knowledge-sharing behavior } \\
\text { among Web } 2.0 \text { and mobile } \\
\text { apps; a negative relationship } \\
\text { in IoT }\end{array}$ & $\begin{array}{l}\text { Willingness leads to actual } \\
\text { knowledge-sharing } \\
\text { behavior; all except Web } 2.0 \\
\text { reduce incidents }\end{array}$ \\
\hline $\begin{array}{l}\text { H7: the practicality issues } \\
\text { lower people's incentives in } \\
\text { sharing knowledge }\end{array}$ & $\begin{array}{c}\text { People do not know how } \\
\text { to use and safety risks on } \\
\text { sites }\end{array}$ & No evidence & No evidence \\
\hline
\end{tabular}

\section{Conclusions}

This study investigated the impact of three psychological factors, i.e. LMX, POS and HP, as well as the institutional factors on construction safety knowledge sharing. The face-to-face and LinkedIn research responses indicated that respondents wished to know more about construction safety, upgrade their knowledge via Web 2.0 and enhance their safety awareness. In sharp contrast, however, individuals who used IoT for knowledge sharing mainly intended to keep "pace of the technology era". IoT was reported to be the least popular tool among those investigated, implying that some people used the devices do not know them well. They used these tools as they do not want to fall behind the curve, but safety-related reasons do not drive them.

Previous research found that people are motivated to use IoT, Web 2.0, and mobile apps in other industries as these tools are easy to use or they can improve processes such as production. These studies considered the use from an individual or the tools' perspective, and none considered the group psychological perspective. This research offers a practical contribution, insights to the key to successful knowledge sharing, informing contractors and employers that we must consider the group 
psychological factors to enhance knowledge sharing. The results can be generalized to other types of work and knowledge which needs to be shared. Academically speaking, most previous research studied the motivations and barriers of knowledge sharing in education, health care and business sectors, so this research fills the void in construction safety research.

Furthermore, PLS-SEM was used to study the impact of the four major groups of psychological motivators: POS, LMX, HP and institutional factors on the willingness and actual knowledge-sharing behavior. Essential factors identified in the PLS-SEM model were then included in the applied artificial intelligence approach, i.e. MLP feed-forward neural network to formulae the model for predicting people's knowledge-sharing behavior. To the best of our knowledge, this approach in studying knowledge-sharing behavior is the first of its kind, offering a new direction to other knowledge-sharing research studies.

Author Contributions: Conceptualization, R.Y.M.L. and K.W.C.; research method, R.Y.M.L.; B.T.; formal analysis, R.Y.M.L.; B.T..; resources, R.Y.M.L., K.W.C; data curation, R.Y.M.L.; B.T..; writing, R.Y.M.L.; B.T.

Funding: This research is funded by Research Grant Council, grant number UGC/FDS15/E01/18 and UGC/FDS15/E01/17.

Conflicts of Interest: The authors declare no conflicts of interest.

\section{References}

1. Li, R.Y.M.; Chau, K.W.; Zeng, F.F. Ranking of Risks for Existing and New Building Works. Sustainability 2019, 11, 2863. [CrossRef]

2. Kim, H.; Han, S. Accuracy Improvement of Real-Time Location Tracking for Construction Workers. Sustainability 2018, 10, 1488. [CrossRef]

3. Oswald, D. The use and abuse of safety indicators in construction. Eng. Constr. Archit. Manag. 2018, 25, 1188-1209. [CrossRef]

4. Shen, X.; Marks, E.; Pradhananga, N.; Cheng, T. Hazardous Proximity Zone Design for Heavy Construction Excavation Equipment. J. Constr. Eng. Manag. 2016, 142, 05016001. [CrossRef]

5. Li, R.Y.M.; Poon, S.W. Using Web 2.0 to Share the Knowledge of Construction Safety as a Public Good in Nature Among Researchers: the Fable of Economic Animals. Econ. Aff. 2011, 31, 73-79. [CrossRef]

6. Dave, B.; Koskela, L. Collaborative Knowledge Management-A Construction Case Study. Autom. Constr. 2009, 18, 894-902. [CrossRef]

7. Zhao, C.; Liu, J.; Shen, F.; Yi, Y. Low power CMOS power amplifier design for RFID and the Internet of Things. Comput. Electr. Eng. 2016, 52, 157-170. [CrossRef]

8. Nourbakhsh, M.; Zin, R.M.; Irizarry, J.; Zolfagharian, S.; Gheisari, M. Mobile Application Prototype for On-site Information Management in Construction Industry. Eng. Constr. Archit. Manag. 2012, 19, 474-494. [CrossRef]

9. Lu, W.; Huang, G.Q.; Li, H. Scenarios for Applying RFID Technology in Construction Project Management. Autom. Constr. 2011, 20, 101-106. [CrossRef]

10. Liu, T. Benefits and barriers in uptake of mobile apps in New Zealand construction industry. Facilities 2019, 37, 254-265. [CrossRef]

11. Elhoseny, M.; Ramírez-González, G.; Abu-Elnasr, O.M.; Shawkat, S.A.; Arunkumar, N.; Farouk, A. Secure Medical Data Transmission Model for IoT-Based Healthcare Systems. Ieee Access 2018, 6, 20596-20608. [CrossRef]

12. Xu, L.D. Information Architecture for Supply Chain Quality Management. Int. J. Prod. Res. 2011, 49, $183-198$. [CrossRef]

13. Bennett, S.; Bishop, A.; Dalgarno, B.; Waycott, J.; Kennedy, G. Implementing Web 2.0 technologies in higher education: A collective case study. Comput. Educ. 2012, 59, 524-534. [CrossRef]

14. Zhang, Y. Research on the development of Internet of Things in Jiangsu and the cultivation of the industry chain. Contemp. Logist. 2013, 13, 31-35.

15. Caruso, S.J. Toward understanding the role of Web 2.0 technology in self-directed learning and job performance. Contemp. Issues Educ. Res. 2018, 11, 89-98. [CrossRef]

16. Hoang, T.V.; Caverly, D.C. Mobile apps and college mathematics. J. Dev. Educ. 2013, 37, 30-31. 
17. Ferguson, R. Use of questions to facilitate social learning in a Web 2.0 environment. RUSC 2011, 8, 316-327. [CrossRef]

18. Chow, H.K.H.; Choy, K.L.; Lee, W.B. A dynamic logistics process knowledge-based system - An RFID multi-agent approach. Knowl. -Based Syst. 2007, 20,357-372. [CrossRef]

19. Sodhro, A.H.; Pirbhulal, S.; Sangaiah, A.K. Convergence of IoT and product lifecycle management in medical health care. Future Gener. Comput. Syst. 2018, 86, 380-391. [CrossRef]

20. Welbourne, E.; Battle, L.; Cole, G.; Gould, K.; Rector, K.; Raymer, S.; Balazinska, M.; Borriello, G. Building the Internet of Things using RFID: The RFID ecosystem experience. Ieee Internet Comput. 2009, 13, 48-55. [CrossRef]

21. Zhang, J.; Puron-Cid, G.; Gil-Garcia, J.R. The influence of political factors in policymakers' perceptions on the implementation of Web 2.0 technologies for citizen participation and knowledge sharing. Inf. Polity 2015, 20, 199-220.

22. Hsu, C.-1.; Park, H.W. Sociology of hyperlink network of Web 1.0, Web 2.0, and Twitter: A case study of South Korea. Soc. Sci. Comput. Rev. 2013, 29, 354-368. [CrossRef]

23. Kulakli, A.; Mahony, S. Knowledge creation and sharing with Web 2.0 tools for teaching and learning roles in so-called University 2.0. Procedia Soc. Behav. Sci. 2014, 150, 648-657. [CrossRef]

24. Mtega, W.P.; Dulle, F.W.; Malekani, A.W.; Chailla, A.M. Awareness and use of Web 2.0 technologies in sharing of agricultural knowledge in Tanzania. Knowl. Manag. E-Learn. 2014, 6, 188-202.

25. Noh, M.J.; Lee, K.T. An analysis of the relationship between quality and user acceptance in smartphone apps. Inf. Syst. E-Bus. Manag. 2016, 14, 273-291. [CrossRef]

26. Said, E.; Arcila, C. The cyber media in Latin America and Web 2.0. Comunicar 2011, 19, 125-131. [CrossRef]

27. Einav, L.; Levin, J.; Popov, I.; Sundaresan, N. Growth, adoption, and use of mobile E-commerce. Am. Econ. Rev. 2014, 104, 489-494. [CrossRef]

28. Furlong, L.; Morris, M.; Serry, T.; Erickson, S. Mobile apps for treatment of speech disorders in children: An evidence-based analysis of quality and efficacy. Plos One 2018, 13, 1-12. [CrossRef]

29. Handal, B.; Novak, A.; Watson, K.; Maber, M.; MacNish, J.; Eddler-Hirsh, K. Numeracy education through mobile apps. Aust. J. Middle Sch. 2014, 14, 28-37.

30. Kenny, R.; Dooley, B.A.; Fitzgerald, A. Developing mental health mobile apps: exploring adolescents' perspectives. Health Inform. J. 2016, 22, 265-275. [CrossRef]

31. Sim, J.-Z.; Zang, Y.; Nguyen, P.-V.; Leow, M.K.-S.; Gan, S.K.-E. Thyroid-SPOT for mobile devices: Personalised thyroid treatment management app. Sci. Phone Apps Mob. Devices 2017, 3, 1-5. [CrossRef]

32. Thornton, L.; Quinn, C.; Birrell, L.; Guillaumier, A.; Shaw, B.; Forbes, E.; Deady, M.; Kay-Lambkin, F. Free smoking cessation mobile apps available in Australia: A quality review and content analysis. Aust. New Zealand J. Public Health 2017, 41, 625-630. [CrossRef] [PubMed]

33. Wai, I.; Ng, S.; Chiu, K.; Ho, K.; Lo, P. Exploring undergraduate students' usage pattern of mobile apps for education. J. Librariansh. Inf. Sci. 2016, 50, 1-29. [CrossRef]

34. Powell, K.H.; Dalton, M.M. Co-Production, Service Exchange Networks, and Social Capital. Soc. Policy J. 2003, 2, 89-106. [CrossRef]

35. Wang, H.-K.; Tseng, J.-F.; Yen, Y.-F. How do institutional norms and trust influence knowledge sharing? An institutional theory. Innovation 2014, 16, 374-391. [CrossRef]

36. Knippenberg, D.v.; Prooijen, J.W.v.; Sleebos, E. Beyond Social Exchange: Collectivism's Moderating Role in the Relationship Between Perceived Organizational Support and Organizational Citizenship Behaviour. Eur. J. Work Organ. Psychol. 2015, 24, 152-160. [CrossRef]

37. Smith, T.N.J. Knowledge Sharing in Projects: does Employment Arrangement Matter? Pers. Rev. 2015, 44, 255-269.

38. Li, R.Y.M. Construction Safety and Waste Management: An Economic Analysis; Springer: Berlin/Heidelberg, Germany, 2015.

39. Krafft, M.; DeCarlo, T.E.; Poujol, F.J.; Tanner, J.F.J. Compensation and Control Systems: A New Application of Vertical Dyad Linkage Theory. J. Pers. Sell. Sales Manag. 2012, 32, 107-115. [CrossRef]

40. Su, T.; Wang, Z.; Lei, X.; Ye, T. Interaction Between Chinese Employees' Traditionality and Leader-member Exchange in Relation to Knowledge-sharing Behaviors. Soc. Behav. Personal. 2013, 41, 1071-1082.

41. Bathelt, H.; Glückler, J. Institutional change in economic geography. Prog. Hum. Geogr. 2013, 38, 340-363. [CrossRef] 
42. Sanaei, M.; Javernick-Will, A.N.; Chinowsky, P. The Influence of Generation on Knowledge Sharing Connections and Methods in Construction and Engineering Organizations Headquartered in the US. Constr. Manag. Econ. 2013, 31, 991-1004. [CrossRef]

43. Li, R.Y.M. Generation X and Y's demand for homeownership in Hong Kong. Pac. Rim Prop. Res. J. 2015, 21, 15-36. [CrossRef]

44. Arpaci, I.; Baloğlu, M. The impact of cultural collectivism on knowledge sharing among information technology majoring undergraduates. Comput. Hum. Behav. 2016, 56, 65-71. [CrossRef]

45. Rödiger, M. Organic consumers' price knowledge, willingness-to-pay and purchase decision. Br. Food J. 2016, 118, 2732-2743. [CrossRef]

46. Kollmuss, A.; Agyeman, J. Mind the Gap: Why do people act environmentally and what are the barriers to pro-environmental behavior? Environ. Educ. Res. 2002, 8, 239-260. [CrossRef]

47. Shin, T.H.; Chin, S.; Yoon, S.W.; Kwon, S.W. A Service-oriented Integrated Information Framework for RFID/WSN-based Intelligent Construction Supply Chain Management. Autom. Constr. 2011, 20, 706-715. [CrossRef]

48. Gyi, D.E.; Haslamt, R.A.; Gibb, A.G.F. Case Studies of Occupational Health Management in the Engineering Construction Industry. Occup. Med. 1998, 48, 263-271. [CrossRef]

49. Denda, K. Developing Interview Skills and Visual Literacy: A New Model of Engagement for Academic Libraries. Libr. Acad. 2015, 15, 299-314. [CrossRef]

50. IBM. IBM SPSS Modeler Text Analytics 15 User's Guide; IBM: Armonk, NY, USA, 2012.

51. Sabi, H.M.; Uzokab, F.M.E.; Langmia, K.; Njeh, F.N. Conceptualizing a Model for Adoption of Cloud Computing in Education. Int. J. Inf. Manag. 2016, 36, 183-191. [CrossRef]

52. Su, C.-H.; Cheng, T.-W. A Sustainability Innovation Experiential Learning Model for Virtual Reality Chemistry Laboratory: An Empirical Study with PLS-SEM and IPMA. Sustainability 2019, 11, 1027. [CrossRef]

53. Chong, A.Y.-L.; Bai, R. Predicting open IOS adoption in SMEs: An integrated SEM-neural network approach. Expert Syst. Appl. 2014, 41, 221-229. [CrossRef]

54. Maghrebi, M.; Sammut, C.; Waller, S.T. Feasibility Study of Automatically Performing the Concrete Delivery Dispatching through Machine Learning Techniques. Eng. Constr. Archit. Manag. 2015, 22, 573-590. [CrossRef]

55. Ghritlahre, H.K.; Prasad, R.K. Exergetic performance prediction of solar air heater using MLP, GRNN and RBF models of artificial neural network technique. J. Environ. Manag. 2018, 223, 566-575. [CrossRef] [PubMed] 